\title{
ANALYSIS OF THE TIME COURSE OF A BRIDGE ABUTMENTS SETTLEMENT
}

\author{
LuBOŠ HRUŠTineC
}

\begin{abstract}
Slovak University of Technology, Faculty of Civil Engineering, Department of Geotechnics, Radlinského 11, 81005 Bratislava, Slovak Republic

correspondence: lubos.hrustinec@stuba.sk
\end{abstract}

\begin{abstract}
The paper deals with the time course of the bridge abutments settlement (consolidation of the subsoil) on the motorway D4 in Stupava, Slovakia. The bridge abutments are founded on an earth embankment 5.5 meters in height and a group of piles. Over 6 years of geotechnical monitoring after the construction of bridge abutments, there were measured settlements from 102 to $106 \mathrm{~mm}$. The measured settlement of intermediate bridge piers was only up to $16 \mathrm{~mm}$. Geotechnical calculations and analysis are focused on the comparison of the final settlements prognosis and its time course with the real measured values.
\end{abstract}

KEYwORDS: Bridge abutment, geotechnical calculations, settlement, consolidation.

\section{INTRODUCTION}

Bridge objects No. 211-01 and 211-02 are situated at the crossroads "Stupava" of the D4 motorway, which is bridging the D2 motorway in the direction from Bratislava to Stupava. A three-span bridge structure of total length $100.9 \mathrm{~m}$ and width $26.15 \mathrm{~m}$ was put into operation in 2010. Bridge abutments are founded on piles in an embankment $5.5 \mathrm{~m}$ high. On the bridge supports, vertical deformations (settlements) have been continuously measured. In the time period from March 2010 to September 2016 (an overall period of 6.5 years) settlement of the internal piers was measured to be from 12.7 to $16.0 \mathrm{~mm}$ and settlement of the bridge abutments from 102 to $106 \mathrm{~mm}$. Such an uneven settlement (maximum angular deformation is $\Delta \mathrm{s} / \mathrm{L}=0.0034$ ) causes a significant increase of internal forces in the bearing elements of the bridge structure (especially in the bridge deck) due to the deformation load. In order to avoid failure of the bridge structure, an over-limit uneven settlement had to be eliminated by inserting compensating steel plates into the bridge bearing of the abutments. The paper deals with prognosis of the time course of the subsoil consolidation of the bridge abutments and the causes of their over-limit uneven settlement. This problem is solved in detail in [1].

\section{ENGINEERING AND GEOLOGICAL CHARACTERISTICS OF THE TERRITORY UNDER STUDY}

Engineering and geological conditions of the studied territory and soil properties of the subsoil have been assessed on the basis of archive documentation [2]. The subsoil is formed by quaternary and neogene soils. Quaternary soils are represented by deluvial, eolian, proluvial and fluvial sediments. Neogene sediments are located in the whole area under quaternary sediments in the form of alternation of the clayey and sandy soils. In the location of bridge structure No. 211 the JM-5 to JM-8 exploration boreholes were conducted to a depth of $15 \mathrm{~m}$. The layers of quaternary fluvial non-cohesive sediments occur in the form of sandy soils. In accordance with STN 721001 [3] soils belong to classes: silty sand (S4-SM) and clayey sand (S5-SC). The thickness of the quaternary layer ranges from $0.7 \mathrm{~m}$ (borehole JM-5) up to $1.7 \mathrm{~m}$ below the surface (borehole JM-6). Under the quaternary sandy soils there are neogene clay soils. The clays belong to certain classes: clay with medium plasticity $(\mathrm{F} 6-\mathrm{Cl})$ and clay with high plasticity (F8-CH). The consistency of the clay changes with the increasing depth, from firm to stiff. In the JM-8 borehole, the clay consistency is soft to firm. The groundwater level was found at 0.7 to $1.0 \mathrm{~m}$ below the surface. The above mentioned information and knowledge have been taken into account when determining the subsoil model and soil properties used in the geotechnical calculations.

\section{Determination of the Subsoil MODELS AND SOIL PROPERTIES}

For bridge abutments No. 1 and No. 4 the subsoil models were defined based on the evaluation of JM- 5 and JM-8 boreholes, respectively. Computational models of subsoil and bridge abutments used in the geotechnical calculations are shown in Figure 1 The depth of the exploration boreholes (JM-5 and JM-8) was $15 \mathrm{~m}$ under the original terrain. Geotechnical calculations showed that the deformation zone (HA) extends to a depth of $22.3 \mathrm{~m}$ below the terrain. Based on the evaluation of the results of the geodetic measurements of the settlements and geotechnical calculations, it was assumed in the subsoil models that from the depth of $15 \mathrm{~m}$ to the depth of the deformation zone "HA" 
there are soils of class F8-CH with soft to firm consistency. The soil properties used in the geotechnical calculations are shown in Table 1 .

\section{TeChnical Parameters of the BRIDGE STRUCTURE}

Information about the technical parameters of the bridge structure were taken from [4]. The bridge loadbearing structure (bridge deck) is a monolithic structure made of pre-stressed concrete of class C35/45 with total height of $1.8 \mathrm{~m}$. The three-span bridge beam has a range of fields $26.5+36.5+26.5 \mathrm{~m}$. The total length of the bridge structure is $100.9 \mathrm{~m}$ (Figure 21. In the transverse direction, the bridge consists of two separate structures. For the right traffic lane, the bridge is marked as No.211-01 and for the left traffic lane No. 211-02 (Figure 3). In the cross-section, two pre-stressed concrete beams are connected with a reinforced concrete slab (bridge deck). The total width in the transverse direction of the bridge is $13.75 \mathrm{~m}$ (structure No. 211-01), and $11 \mathrm{~m}$ (structure No. 21102). Geometric boundary conditions of the abutment structures No. 1 and 4 (including embankment and backfill) for structures No. 211-01 and No. 211-02 have been taken from the project documentation 4. Bridge abutments are deep founded on piles and on the embankment (Figure 2). The foundation consists of a group of piles with a diameter of $0.9 \mathrm{~m}$, a length of $14 \mathrm{~m}$ (No. 211-01 group of 7 piles and No. 211-02 group of 6 piles). Computational models of bridge abutments No. 1 and 4 are shown in Figure 1 .

\section{Determination of loAd states FOR GEOTECHNICAL CALCULATIONS}

The loads due to the bridge structures were taken from the static analysis mentioned in [1]. The total loads acting on the bridge abutments and subsoil are shown in Table 2 In the geotechnical calculations, the most significant loads of the subsoil from the individual structures (embankment, abutment and the backfill behind the abutment) and the technological progress of the construction of bridge structures No. 211-01 and 211-02, were considered. Three following load states were defined:

- $1^{\text {st }}$ Load state $\left(1^{\text {st }} \mathrm{LS}\right)$ : construction of the embankment below the abutments. Under the abutment No. 1 the height of the embankment is $\mathrm{h}_{n 1}=$ $5.5 \mathrm{~m}$, which causes a uniform plane load $\mathrm{q}_{n 1}=$ $\gamma \times h_{n 1}=20 \times 5.5=110 \mathrm{kNm}^{-2}$. Under the abutment No. 4 the height of the embankment is $\mathrm{h}_{n 4}=4.8 \mathrm{~m}$, which causes a uniform plane load $\mathrm{q}_{n 4}=\gamma \times h_{n 4}=20 \times 4.8=96 \mathrm{kNm}^{-2}$.

- $2^{\text {nd }}$ Load state ( $\left.2^{\text {nd }} \mathrm{LS}\right)$ : construction of piles, abutments and bridge decks (Table 2 ).

- $3^{\text {rd }}$ Load state $\left(3^{\text {rd }} \mathrm{LS}\right)$ : construction of a backfill behind the bridge abutments. Behind the abutments the height of the backfill is $\mathrm{h}_{z}=4.3 \mathrm{~m}$, which causes a load of size $\mathrm{q}_{z}=\gamma \times h_{z}=20 \times 4.3=86 \mathrm{kNm}^{-2}$.

From the defined load states it follows that the total load of the subsoil at the level of the terrain from embankments and backfills, causes the load of up to $\mathrm{q}_{1}=196 \mathrm{kNm}^{-2}$ (for abutment No. 1) and $\mathrm{q}_{4}=182 \mathrm{kNm}^{-2}$ (for abutment No.4). The total vertical load acting locally below the abutments (at the foundation gap) has a size $\mathrm{q}^{211-01}=220.9 \mathrm{kNm}^{-2}$ (for abutment No. 211-01) and $\mathrm{q}^{211-01}=232.5 \mathrm{kNm}^{-2}$ (for abutment No.211-01). From these values of load intensity it is obvious that the large embankment and backfill will have a significant impact on the final settlement of the abutments and cannot be neglected in the calculations.

\section{Results FROM GEODETICAL MEASUREMENTS OF THE BRIDGE SUPPORTS SETTLEMENT}

The vertical displacements (settlements) of the bridge supports have been continuously measured using the geodetic method of a very precise levelling. In the period from July 13, 2010 to September 3, 2016 (i.e. over 6 years), a total of 23 stage measurements have been performed. The detailed results of the geodetic measurements are given in [1. Graphical evaluation of the time course of settlement of supports No. 1 to 4 of the bridge structure No. 211-01 and No. 211-02 is shown in Figure 4. The measured maximum settlements of the middle piers were 12.7 to $16.0 \mathrm{~mm}$ and the settlements of the edge bridge abutments were 102.0 to $106.0 \mathrm{~mm}$. From the static analysis of a bridge structure, the maximum value of the settlement difference of the neighbouring supports $\Delta \mathrm{s}=20$ $\mathrm{mm} 11$ resulted. The measured maximum settlement difference of the neighbouring supports is $\Delta \mathrm{s}=106$ $16=90 \mathrm{~mm}$ and maximal uneven settlement is $\Delta / \mathrm{L}$ $=90 / 26500=0.0034$. The above-mentioned overlimit uneven settlement causes a significant increase of the internal forces in the bridge bearing elements (especially in the bridge deck) due to the deformation load. To compensate for the over-limit uneven settlements of the bridge supports, the bridge deck structures at the place of abutments were lifted and steel washers with a thickness of $45 \mathrm{~mm}$ were inserted on November 15, 2010.

\section{Evaluation of geotechnical CALCULATIONS}

The geotechnical calculations were focused on the determination of the rate of the final settlement and the time course of settlements of the bridge abutments No. 1 and 4. The calculations were performed in accordance with valid standards [5, 6]. The final settlement was calculated using the finite element method (planar task) and the time course of settlements was analyzed in terms of the theoretical assumptions of 


\begin{tabular}{|c|c|c|c|c|c|c|c|}
\hline $\begin{array}{c}\text { Geological } \\
\text { period }\end{array}$ & Soil & Class-symbol & Consistency & $\begin{array}{c}\gamma \\
{\left[\mathbf{k N} / \mathbf{m}^{3}\right]}\end{array}$ & $\begin{array}{c}\nu \\
{[-]}\end{array}$ & $\begin{array}{c}\mathbf{E} \\
{[\mathrm{MPa}]}\end{array}$ & $\begin{array}{c}\mathbf{c}_{v} \\
{\left[\mathbf{m}^{2} \cdot \mathbf{s}^{-1}\right]}\end{array}$ \\
\hline \multirow{3}{*}{ Quaternary } & $\begin{array}{l}\text { Silt with low } \\
\text { plasticity }\end{array}$ & F5-ML & firm & 20.0 & 0.40 & 4.0 & $5.0 \mathrm{E}-06$ \\
\hline & Silt sand & S4-SM & fine fraction is firm & 18.0 & 0.30 & 8.0 & $7.5 \mathrm{E}-05$ \\
\hline & Clayey sand & S5-SC & $\begin{array}{l}\text { fine fraction is } \\
\text { soft firm }\end{array}$ & 18.5 & 0.35 & 8.0 & $3.8 \mathrm{E}-06$ \\
\hline \multirow{5}{*}{ Neogene } & $\begin{array}{c}\text { Clay with medium } \\
\text { plasticity }\end{array}$ & F6-CI & soft to firm & 21.0 & 0.40 & 3.0 & $5.4 \mathrm{E}-07$ \\
\hline & $\begin{array}{l}\text { Clay with high } \\
\text { plasticity }\end{array}$ & $\mathrm{F} 8-\mathrm{CH}$ & soft to firm & 20.5 & 0.42 & 2.0 & $2.2 \mathrm{E}-07$ \\
\hline & $\begin{array}{l}\text { Clay with high } \\
\text { plasticity }\end{array}$ & $\mathrm{F} 8-\mathrm{CH}$ & firm & 20.5 & 0.42 & 3.0 & $2.2 \mathrm{E}-07$ \\
\hline & $\begin{array}{l}\text { Clay with high } \\
\text { plasticity }\end{array}$ & $\mathrm{F} 8-\mathrm{CH}$ & firm to stiff & 20.5 & 0.42 & 4.0 & $2.2 \mathrm{E}-07$ \\
\hline & $\begin{array}{l}\text { Clay with high } \\
\text { plasticity }\end{array}$ & $\mathrm{F} 8-\mathrm{CH}$ & stiff & 20.5 & 0.42 & 6.0 & $2.2 \mathrm{E}-07$ \\
\hline
\end{tabular}

TABLE 1. Soil properties used in geotechnical calculations.
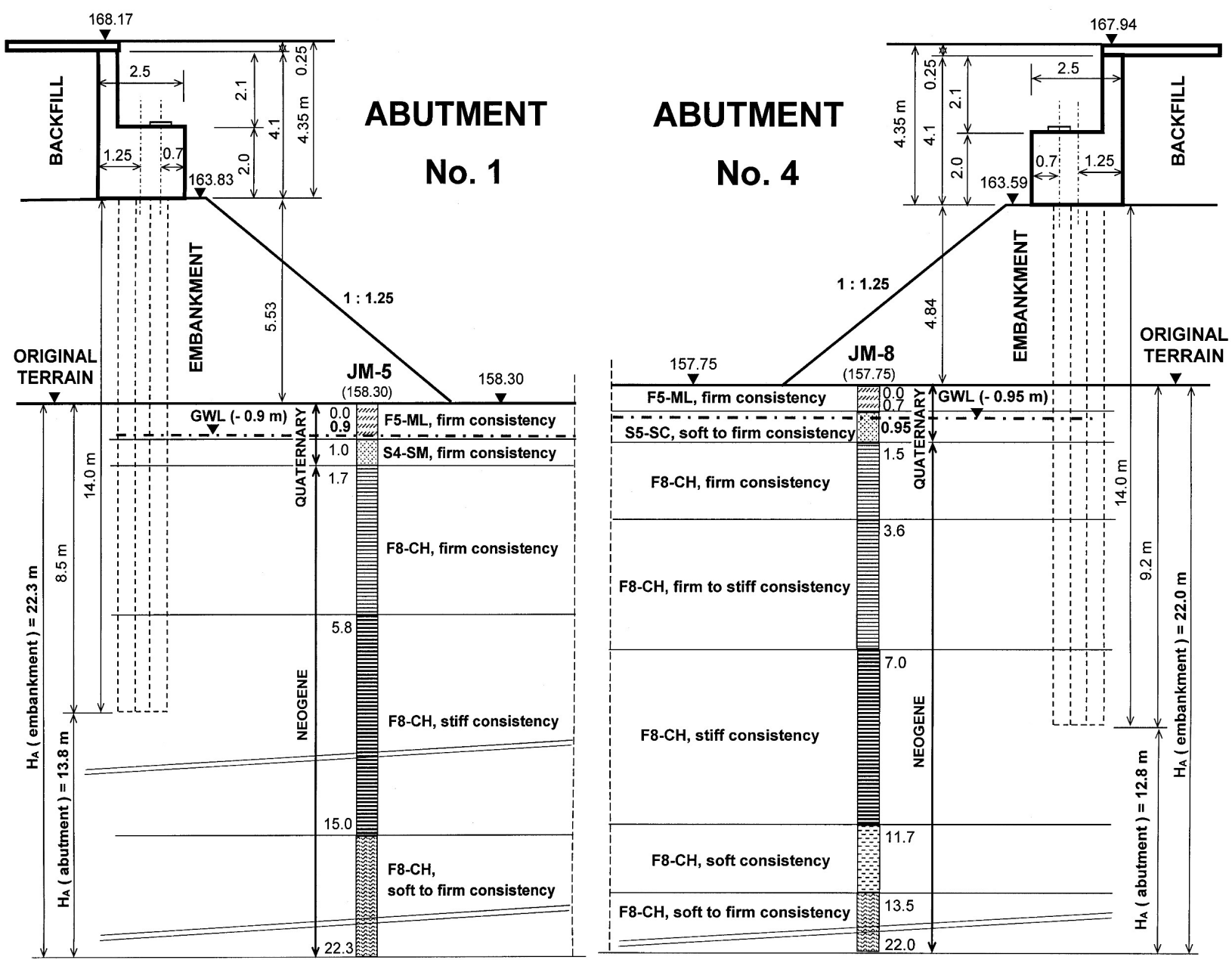

Figure 1. Computational models for abutments No. 1 and 4 used in geotechnical calculations. 
No. 211-01 and No. 211-02

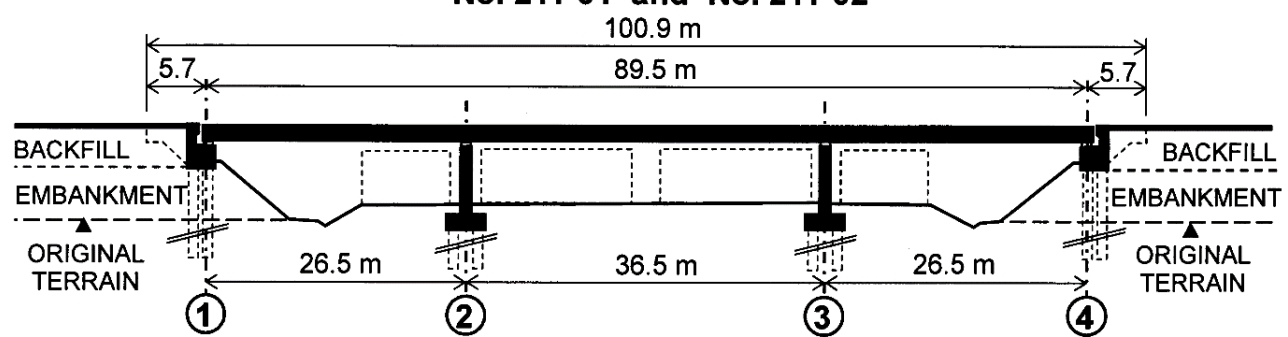

Figure 2. Longitudinal cross section of the bridge structure 4].

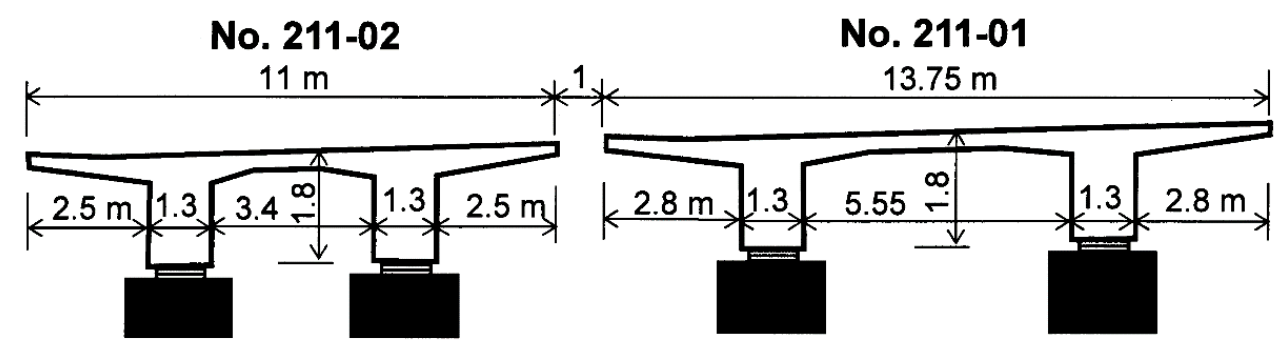

Figure 3. Cross section of the bridge structure 4].

\begin{tabular}{cccccccc} 
Bridge structure & Abutment & Type of load & $\begin{array}{c}\mathbf{V}_{z} \\
{[\mathbf{k N}]}\end{array}$ & $\begin{array}{c}\mathbf{H}_{x} \\
{[\mathbf{k N}]}\end{array}$ & $\begin{array}{c}\mathbf{H}_{z} \\
{[\mathbf{k N}]}\end{array}$ & $\begin{array}{c}\mathbf{M}_{x} \\
{[\mathbf{k N m}]}\end{array}$ & $\begin{array}{c}\mathbf{M}_{y} \\
{[\mathbf{k N m}]}\end{array}$ \\
\hline $211-01$ & 1 and 4 & Dead weight & $7,870.5$ & 0.0 & 0.0 & 0.0 & $2,245.0$ \\
\hline $211-02$ & 1 and 4 & Dead weight & $6,685.3$ & 0.0 & 0.0 & 0.0 & $1,952.3$ \\
\hline
\end{tabular}

TABLE 2. Loads for the bridge abutments used in geotechnical calculations [4.

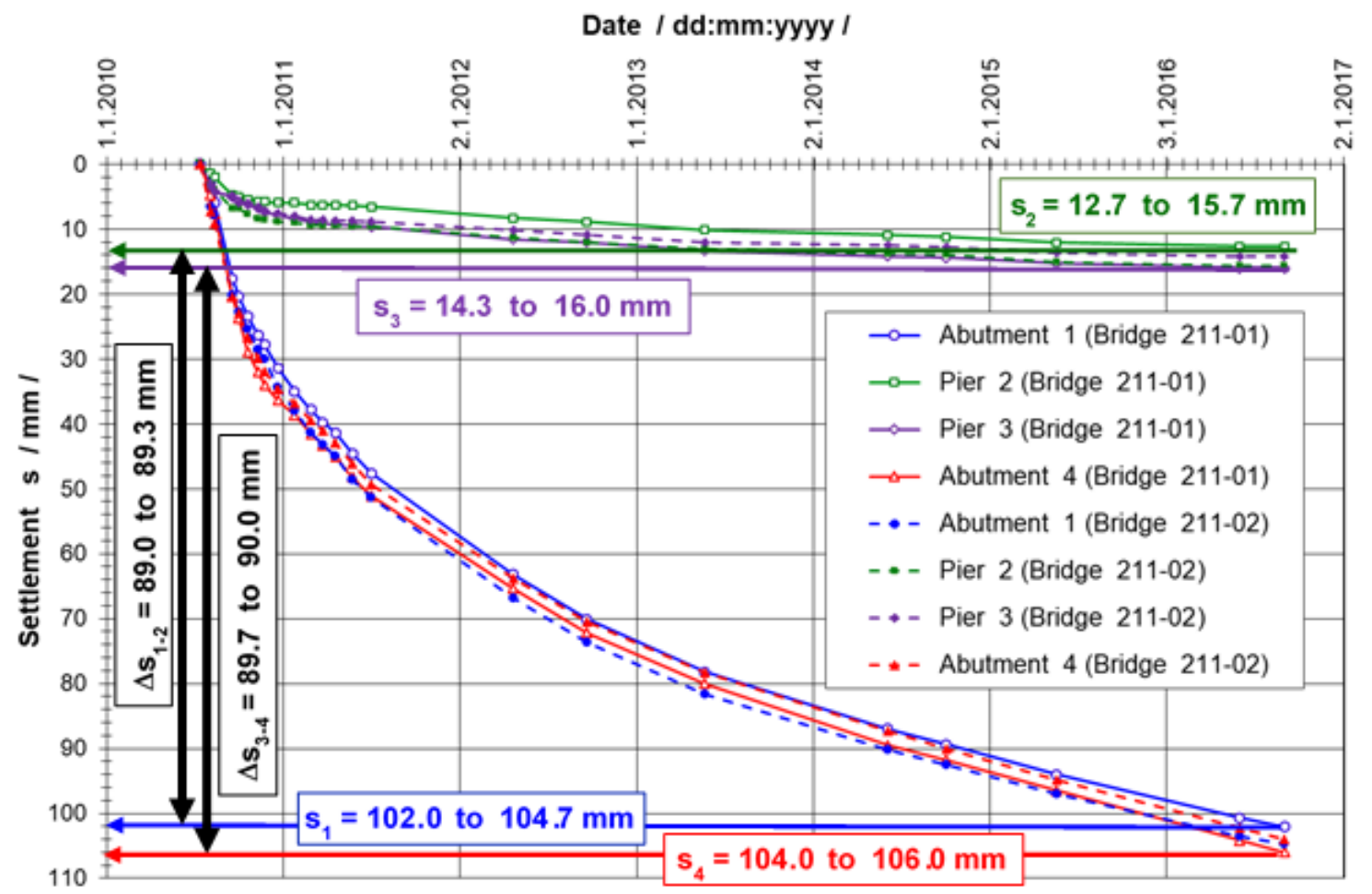

FIGURE 4. The measured time course of settlements $\left(\mathrm{s}_{i}\right)$ of the bridge supports (piers and abutments) and settlements difference $\left(\Delta \mathrm{s}_{i}\right)$ of neighbouring supports. 
Consolidation time / years I

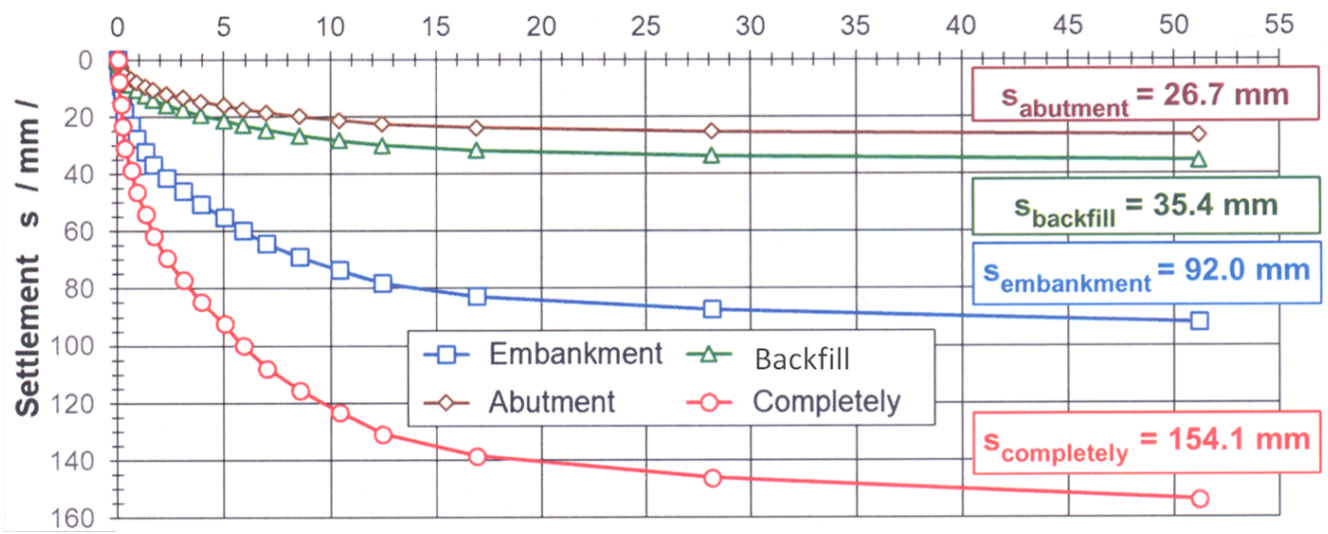

Figure 5. Calculated time course of settlement of the bridge structure No. 211-01, abutment No. 1.

\begin{tabular}{|c|c|c|c|c|c|c|c|}
\hline \multirow{3}{*}{$\begin{array}{l}\text { Bridge } \\
\text { structure }\end{array}$} & \multirow{3}{*}{ Abutment } & \multicolumn{4}{|c|}{ Calculated final settlement $\mathrm{s}$} & \multirow{2}{*}{$\begin{array}{c}\text { Measured } \\
\text { settlement } \\
(3.9 .2016)\end{array}$} & \multirow{2}{*}{$\begin{array}{l}\text { Settlements } \\
\text { (difference } \\
\text { calc.-meas.) }\end{array}$} \\
\hline & & Abutment & Embankment & Backfill & $\begin{array}{l}\text { Completely (embankment, } \\
\text { abutment, backfill) }\end{array}$ & & \\
\hline & & $\begin{array}{c}\mathbf{s}_{a} \\
{[\mathrm{~mm}]}\end{array}$ & $\begin{array}{c}\mathbf{s}_{e} \\
{[\mathrm{~mm}]}\end{array}$ & $\begin{array}{c}\mathbf{s}_{b} \\
{[\mathrm{~mm}]}\end{array}$ & $\begin{array}{c}\mathbf{s}_{c} \\
{[\mathbf{m m}]}\end{array}$ & $\begin{array}{c}\mathbf{s}_{m} \\
{[\mathbf{m m}]}\end{array}$ & $\begin{array}{c}\Delta \mathbf{s}_{c} \\
{[\mathbf{m m}]}\end{array}$ \\
\hline \multirow{2}{*}{ 211-01 } & 1 & 26.65 & 92.00 & 35.45 & 154.10 & 102.00 & 52.10 \\
\hline & 4 & 34.45 & 86.60 & 40.70 & 161.75 & 106.00 & 55.75 \\
\hline \multirow{2}{*}{$211-02$} & 1 & 28.30 & 93.15 & 36.20 & 157.65 & 104.70 & 52.95 \\
\hline & 4 & 32.90 & 85.30 & 38.25 & 156.45 & 104.00 & 52.45 \\
\hline
\end{tabular}

TABLE 3. Comparison of calculated and measured settlements with the prognosis of further settlement $\Delta \mathrm{s}_{c}[\mathrm{~mm}]$.

one-dimensional consolidation [7]. Geotechnical calculations yielded many quantitative and qualitative results. The detailed results of the calculations can be found in the author's archive records. This article presents only some representative results of geotechnical calculations and their processing in a clear tabular and graphical form. Graphical evaluation of the calculated time course of settlement of the individual structural parts (embankment, abutment, backfill, and the complete structure) of the abutment No. 1 (bridge No. 211-01) is shown in Figure 5.

The table comparison of the measured (as of September 3,2016$)$ and the calculated values of the final settlements of the bridge abutments with the prognosis of expected increase of settlement $\Delta \mathrm{s}$ is given in Table 3 The relative percentage comparison with the calculated final settlement is presented in Table 4. The graphical evaluation of the comparison of the measured settlements and the calculated final settlements of bridge structure No. 211-01 for a period of 0 to 10 years is shown in Figure 6. From the evaluation and analysis of the results of the geotechnical calculations and a comparison with the measured settlements, the following facts and knowledge follow:

- Calculated values of the final settlements (average values in the centre of abutments) range from $154.1 \mathrm{~mm}$ (bridge No. 211-01, abutment No. 1) to $161.75 \mathrm{~mm}$ (bridge No.211-01, abutment No.4). From the total value of the final settlements, the effects of loads due to the individual structural parts is the following: due to the embankment up to $59.7 \%$ (from 54.5 to $59.7 \%$ ), due to the backfill behind the abutment it is up to $25.2 \%$ (from 23.0 to $25.2 \%$ ) due to the subsoil loading by the abutment structure it is to $21.3 \%$ (from 17.3 to $21.3 \%$ ). From the above mentioned it follows that the final value of the settlement is mainly affected by loading of the subsoil by the embankment and the backfill behind abutment. The final settlement caused by the embankment and backfill causes up to $82.7 \%$ (from 78.7 to $82.7 \%$ ) of the total final settlements of the bridge abutments. The size of the calculated settlements is also significantly affected by the presence of clays soils with soft consistency in the bridge abutments subsoil.

- The calculations results of the time course of settlements (under the assumed boundary conditions) showed that the subsoil consolidation will be finished (consolidation degree $\mathrm{U}=100 \%$ ) after 51.1 years (Figure 5), or $80 \%$ degree of consolidation will be achieved after 10 years (Figure 6).

- From the comparison of the measured settlements (as of September 3, 2016) and the calculated final settlements, there is the result that the measured values reach up to $66.5 \%$ of the final settlements, i.e. approximately $2 / 3$ of the final settlements value (Table 4). The expected next settlements $\Delta \mathrm{s}$ of the bridge abutments are in the range from $52.1 \mathrm{~mm}$ to 


\begin{tabular}{|c|c|c|c|c|c|c|c|}
\hline \multirow{3}{*}{$\begin{array}{l}\text { Bridge } \\
\text { structure }\end{array}$} & \multirow{3}{*}{ Abutment } & \multicolumn{4}{|c|}{ Calculated final settlement $\mathrm{s}$} & \multirow{2}{*}{$\begin{array}{c}\text { Measured } \\
\text { settlement } \\
(3.9 .2016)\end{array}$} & \multirow{2}{*}{$\begin{array}{c}\text { Settlements } \\
\text { difference } \\
\text { (calc.-meas.) }\end{array}$} \\
\hline & & Abutment & Embankment & Backfill & $\begin{array}{l}\text { Completely (embankment } \\
\text { abutment, backfill) }\end{array}$ & & \\
\hline & & $\begin{array}{c}\mathbf{s}_{o} \\
{[\%]}\end{array}$ & $\begin{array}{c}\mathbf{s}_{n} \\
{[\%]}\end{array}$ & $\begin{array}{l}\mathbf{s}_{z} \\
{[\%]}\end{array}$ & $\begin{array}{c}\mathbf{s}_{c} \\
{[\%]}\end{array}$ & $\begin{array}{c}\mathbf{s}_{m} \\
{[\%]}\end{array}$ & $\begin{array}{l}\Delta \mathbf{s}_{c} \\
{[\%]}\end{array}$ \\
\hline \multirow{2}{*}{ 211-01 } & 1 & 17.3 & 59.7 & 23.0 & 100.0 & 66.2 & 33.8 \\
\hline & 4 & 21.3 & 53.5 & 25.2 & 100.0 & 65.5 & 34.5 \\
\hline \multirow{2}{*}{ 211-02 } & 1 & 18.0 & 59.1 & 23.0 & 100.0 & 66.4 & 33.6 \\
\hline & 4 & 21.0 & 54.5 & 24.0 & 100.0 & 66.5 & 33.5 \\
\hline
\end{tabular}

TABLE 4. The percentage comparison of calculated and measured settlements.

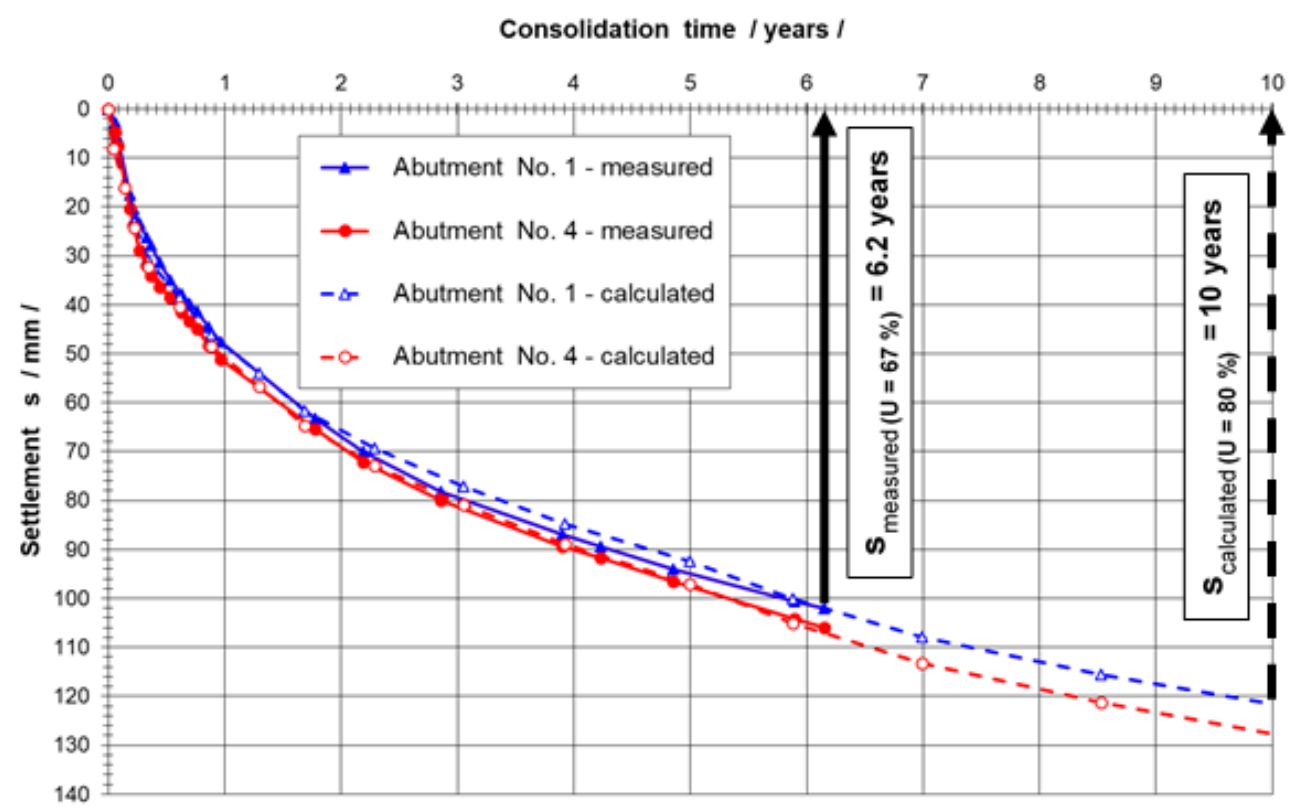

FiguRE 6. Time course of settlement of the bridge structure No. 211-01, abutments No. 1 and 4 - comparison of measured and calculated values over a 10-year period.

$55.75 \mathrm{~mm}$ (Table 3), i.e. 33.5 to $34.5 \%$ of the final settlements (Table 4).

The above findings must be taken into account in the complex assessment of the reliability of the bridge structures No. 211-01 and No. 211-02.

\section{Conclusions}

Based on the analysis and evaluation of the geotechnical calculations undertaken it can be stated that the over-limit settlements of the bridge abutments occurred mainly due to the following factors:

- Failures during the execution of the geotechnical survey (mainly insufficient depth of survey boreholes that did not reach the depth of the deformation zone; ending boreholes in cohesive soils of soft consistency; insufficient determination of geotechnical data valid for soils in the subsoil).

- Failures during the execution of the geotechnical calculations and design of the bridges abutments (especially neglecting the significant part of the loading of the subsoil due to the embankment and the backfill bridge abutments; neglecting the consolidation processes in the subsoil).

To ensure the reliable operation of bridge objects No. 211-01 and No. 211-02, the following recommendations and proposed measures were formulated:

- At regular intervals, to visually check the bridge structures and their load-bearing elements. During the bridge checking it is necessary to focus on deformation of the structures (including the embankment and the surrounding terrain), the origins of cracks and other disproportional phenomena (deformation of the terrain, inadequate deformations and rotation, etc.).

- To perform ongoing geodetic measurements of vertical displacements (settlements) of bridge supports No. 1 to 4 (including internal piers No. 2 and No. 3 ) at a minimum of twice per year.

- After each periodic measurement it is necessary to graphically evaluate the measured values of settlement and to compare them with the calculated values. If the measured settlement values are not 
in accordance with the expected values, it is necessary to take measures to eliminate the uneven settlements and their effects on the reliability of the bridge structure. This involves following the recommendations of the static analysis of the bridge structure, such as e.g., inserting washers into the abutments bridge bearings.

- If the measured settlements are higher than the expected ones, or they progressively rise, it is necessary to carry out an additional geotechnical survey to the depth of the deformation zone.

- In case of another disproportional progressive increase of the settlements, it is necessary to take more complex measures, such as e.g., pre-injection of the subsoil using jet grouting technology.

\section{LIST OF SYMBOLS}

$\gamma$ Unit weight with natural moisture $\left[\mathrm{kN} \mathrm{m}^{-3}\right]$

$\nu$ Poissin ratio [-]

$E_{\text {def }}$ Modulus of deformation [MPa]

$c_{v}$ Coefficient of consolidation $\left[\mathrm{m}^{2} \mathrm{~s}^{-1}\right]$

$V_{y}$ Vertical force $[\mathrm{kN}]$

$H_{x}$ Horizontal force in the $\mathrm{x}$-axis direction $[\mathrm{kN}]$

$H_{y}$ Horizontal force in the $\mathrm{y}$-axis direction $[\mathrm{kN}]$

$M_{x}$ Moment in the x-axis direction [kNm]

$M_{x}$ Moment in the y-axis direction $[\mathrm{kNm}]$

$s$ Settlement; vertical displacement [mm]

$\Delta s$ Settlement difference $[\mathrm{mm}]$

$U$ Degree of consolidation [\%]

\section{ACKNOWLEDGEMENTS}

The author is grateful for support from the Grant Agency VEGA of the Slovak Republic, project No. 1/0412/18.

\section{REFERENCES}

[1] J. Halovonik. Assessment of stress in the bridges structures no. 211-01 and 211-02 - crossroad Stupava. Bratislava, 2016.

[2] I. Modlidba. Crossroad stupava - south on the D2 motorway. A detailed engineering-geological survey. Final report. TERRATEST. Bratislava, 2006.

[3] STN EN 72 1001: Classification of soil and rock in engineering geology and geotechnics, 2010.

[4] M. Sloboda. Crossroad Stupava - South on the D2 motorway. Documentation of actual construction. STRABAG - DOPRASTAV, 2011.

[5] STN EN 1997-1 Eurocode 7: Geotechnical design. Part 1: General rules. 2005.

[6] STN 73 1001: Geotechnical structures. Foundation, 2010.

[7] J. Jesenák. Soil mechanics. STU Bratrislava, 1994. 